\title{
Wastewater Treatment by Electrocoagulation: A comparative study using different anode materials
}

\author{
Khaled Zaher ${ }^{1}$, Abdelsalam Elawwad ${ }^{1}$, Rana Nadeem² \\ ${ }^{1}$ Environmental Engineering Dept., Faculty of Engineering, Cairo University \\ El-Gamaa St., 12613 Giza, Egypt \\ elawwad@cu.edu.eg,dr.khaledzaher@gmail.com \\ ${ }^{2}$ Sanitary and Environmental Engineering Institute, Housing and Building Research Center \\ 87 Tahir St., Dokki, 11511 Giza, Egypt \\ rona.rose@hotmail.com
}

\begin{abstract}
This study investigated COD removal by electrocoagulation in both synthetic and real wastewater using different anode material. Experiments were conducted in a batch-scale EC cell using aluminium, iron and copper electrodes as anode and stainless-steel electrode as cathode. Effects of different parameters including pH (4, 7, and 10), time (10 to $60 \mathrm{~min})$, voltage (3 to $12 \mathrm{~V})$ were studied in order to evaluate the efficiency of electrocoagulation process. The initial synthetic COD concentration was $1000 \mathrm{mg} / \mathrm{l}$. The highest COD removal efficiency of $97.7 \%$ was observed by aluminium electrode under the following conditions: $\mathrm{pH}=7$, time of $60 \mathrm{~min}$, and voltage of $12 \mathrm{~V}$. Moreover, it was observed that most of COD removal happened during the first 10 min (about $86 \%$ ) then the removal rate decreased. For real wastewater, the highest COD removal efficiency was $91.9 \%$ which achieved by using aluminium electrode, $\mathrm{pH}$ $=7.4$, time of $60 \mathrm{~min}$, and voltage of $12 \mathrm{~V}$. The results showed the feasibility of electrocoagulation process for the treatment of highstrength municipal wastewaters.
\end{abstract}

Keywords: Electrocoagulation, Wastewater treatment, Chemical Oxygen Demand, Anode material.

\section{Introduction}

Wastewater contains high organic and nutrient concentrations. So, direct discharge of raw untreated sewage into the water body is one of the main sources of pollution. The main objectives of wastewater treatment are protecting the environment, conserving fresh water resources and wastewater reuse [1]. Nowadays, more effective methods are required to treat a wide range of pollutants. Electrocoagulation (EC) is a promising process in which a sacrificial metal anode produces electrically active coagulants. EC has many advantages as it is fast, simple and cost-effective method. Moreover, it requires lower maintenance cost and needs less labour [2].

EC involves many chemical and physical phenomena that use consumable metal electrodes to supply ions into the water stream. Electrodes are classified into cathode and anode based on the type of reaction occurred on its surface where, reduction occurs at the cathode, while oxidation occurs at the anode [3]. The amount of electricity that passes through the cell governed the amount of substance that undergoes oxidation or reduction at each electrode [4]. Metal anodes continuously scarifies metal ions, which immediately hydrolyse to polymeric metal hydroxide. Pollutants present in wastewater are treated either by chemical coagulation or by attachment to coagulated particles. They are then removed by electro-flotation, sedimentation, or filtration.

The literature indicates that EC can be used to treat water containing pollutants such as: heavy metals, textile wastewater, oily wastewater, food industry, potable water, urban wastewater, oil wastes, Paper Mill Wastewater, and many other pollutants [5-9].

In this study, the authors want to investigate the efficiency of EC process in treating municipal wastewater. EC is a simple technology, needs small footprint and isn't limited by the existence of toxic compounds or $\mathrm{pH}$. So, it can be used in rural areas which suffer in many countries from lack of appropriate sanitation services [10]. The aim of this study is to compare between different anode electrode materials including Aluminum $(\mathrm{Al})$, Iron $(\mathrm{Fe})$, and Copper $(\mathrm{Cu})$ in $\mathrm{EC}$ process used for the removal of chemical oxygen demand (COD) in wastewater. 


\section{Methodology}

The bench-scale EC cell was constructed for the experimental works as shown in figure1. EC reactor consists of one litre Pyrex glass beaker and two electrodes $(15 \mathrm{~cm}$ high, $5 \mathrm{~cm}$ wide and, $0.5 \mathrm{~cm}$ thickness) which were fixed vertically and parallel to each other and they are connected to a variable power supply $(0$ to $12 \mathrm{~V})$. The configuration of the cell is a monopolar configuration and the internal spacing between the two electrodes was $4 \mathrm{~cm}$. The cathode was stainless steel while the anode different ( $\mathrm{Al}, \mathrm{Fe}$ or $\mathrm{Cu}$ ) according to the experiment. The solution was mixed using a magnetic stirrer adjusted to $250 \mathrm{rpm}$. After each experiment, the electrodes were washed using an acid bath $(4 \% \mathrm{HCl})$ and they were carefully cleaned using steel wool to remove any oxides that may have been formed on the surface. All experiments were conducted at room temperature of $24 \pm 2{ }^{\circ} \mathrm{C}$.

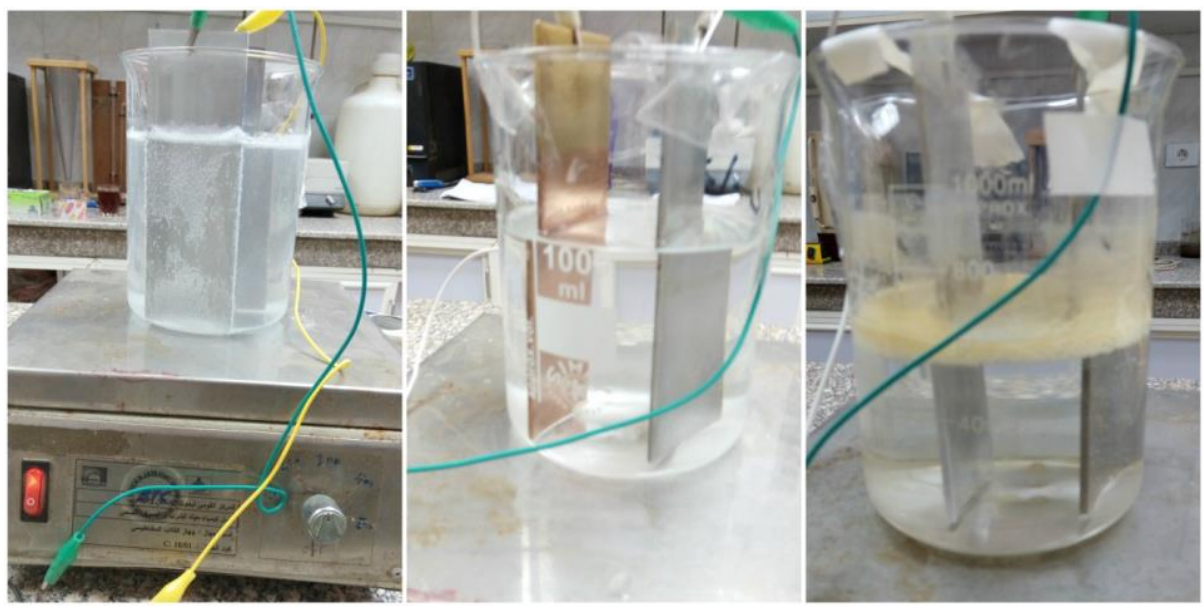

Fig.1: The batch-scale EC cell.

Table 1: Characterizations of synthetic and real wastewater.

\begin{tabular}{|l|c|c|}
\hline Parameter & Synthetic Wastewater & Real Wastewater \\
\hline $\mathrm{pH}$ & 7 & 7.22 \\
\hline $\mathrm{COD} \mathrm{mg} / \mathrm{l}$ & 1000 & 397 \\
\hline $\mathrm{BOD} \mathrm{mg} / \mathrm{l}$ & $\mathrm{NA}$ & 217 \\
\hline Ammonia mg NH$/ / 1$ & 40 & 10.5 \\
\hline Nitrates $\mathrm{mg} \mathrm{NO}_{3} / \mathrm{l}$ & 10 & 0.41 \\
\hline Phosphoru mg/l & 10 & 4.5 \\
\hline Total solids mg/l & 1580 & 710 \\
\hline TSS mg/l & 580 & 198 \\
\hline TDS mg/l & 500 & 512 \\
\hline Conductivity $\mu \mathrm{s} / \mathrm{m}$ & 1110 & 987 \\
\hline Fe mg/l & Zero & 0.1 \\
\hline $\mathrm{Al} \mathrm{mg/l}$ & Zero & Zero \\
\hline Cu mg/l & Zero & Zero \\
\hline Total Alkalinity mg/l & NA & 264 \\
\hline
\end{tabular}

Synthetic wastewater and domestic wastewater were used in the experiments. First experiments were carried out to study the removal of COD in model wastewater. The synthetic wastewater used was prepared using distilled water contains phosphate, nitrates, $1.5 \mathrm{~g} / \mathrm{L}$ soluble starch. Sodium chloride $(\mathrm{NaCl})$ was added with $0.5 \mathrm{~g} / \mathrm{L}$ concentration as a supporting electrolyte to increase conductivity so the power consumption decreases, and the removal efficiency increases electrolytes. Although there are different electrolytes that can be used, $\mathrm{NaCl}$ is the best choice due to its low cost and its availability. All chemicals used in the study were analytical grade. $\mathrm{pH}$ values were adjusted using $1 \mathrm{~N}$ sodium hydroxide $(\mathrm{NaOH})$ and $1 \mathrm{~N}$ hydrochloric acid $(\mathrm{HCl})$. All experiments were performed at Temperature $24^{\circ} \mathrm{C} \pm 2$ and to adjust neutral $\mathrm{pH}=7.0$ except when studying the effect of initial $\mathrm{pH}$. The characteristics of synthetic wastewater were shown in Table 1. 
Further experiments were carried out using real wastewater to study the efficiency of COD removal with optimum conditions obtained during synthetic wastewater experiments. The real wastewater used in the study was obtained from the influent wastewater flow of Zenin wastewater treatment plant, Egypt with the characteristics shown in Table 1.

All samples were collected using sterilized pipettes at regular 10 minutes interval of time (from 10 to 60 minutes). Each time a sample with volume of $5 \mathrm{ml}$ was taken then filtered with Whatman filter paper before analysis. COD was measured for all samples, while, total dissolved solids (TDS), total suspended solids (TSS), conductivity, and pH were measured at the start and end of the experiment. COD was measured in terms of $\mathrm{mg} / \mathrm{l}$ using UV/VIS Spectrometer (PG Instruments Ltd). The analysis model was the closed reflux method at $\lambda 600 \mathrm{~nm}$ according to Standard methods for examination of water and wastewater [11]. Moreover, $\mathrm{Al}, \mathrm{Fe}$, and $\mathrm{Cu}$ concentrations were measured according to the electrode used at the end of each experiment. The removal of pollutants was calculated from the COD values by using Equation (1), where $\mathrm{COD}_{\mathrm{o}}$ and $\mathrm{COD}_{\mathrm{t}}$ are COD at start and at time t, respectively.

$$
\text { Removal } \%=\left(1-\frac{C O D_{o}}{C O D_{t}}\right) \times 100
$$

\section{Results and discussion}

\subsection{Effect of Initial pH of the solution on COD removal}

The effect of solution $\mathrm{pH}$ on COD removal efficiency of EC process was investigated with initial $\mathrm{pH}$ ranged from 4 to 10 . The results showed that $\mathrm{Al}$ electrode has higher efficiency near to neutral $\mathrm{pH}$. At $\mathrm{pH}=7$, COD removal efficiency of $97.7 \%$ was obtained after $60 \mathrm{~min}$, while at $\mathrm{pH}=10$ the removal efficiency was $95.4 \%$ and at $\mathrm{pH}=4$ was $92.2 \%$. Also, the same For Fe electrode, the best performance was also at $\mathrm{pH}=7$ with COD removal efficiency $96.8 \%$, while at $\mathrm{pH}=10$ the removal efficiency was $93.6 \%$ and at $\mathrm{pH}=4.0$ was $92.2 \%$. The lower performance at low $\mathrm{pH}$ values for Fe electrode might be due to the less amount of iron insoluble precipitates which are responsible for coagulation. While lower performance for $\mathrm{Al}$ electrode at low $\mathrm{pH}$ values, $\mathrm{Al}$ species will be in the form of $\mathrm{Al}^{3+}$ and $\mathrm{Al}(\mathrm{OH})^{2+}$. Therefore, effective electrocoagulation did not happen in liquids with low $\mathrm{pH}[3,12,13]$. In contrast, the best performance for Cu electrode was at Alkaline media $(\mathrm{pH}=10)$. At $\mathrm{pH}=10$, COD removal efficiency was $95.5 \%$, while it was $94.6 \%$ and at $\mathrm{pH}=7$ and only $91.9 \%$ at $\mathrm{pH}=4.0$. Different values of COD removal at different $\mathrm{pH}$ might be due to the quality and quantity of copper hydroxide ions formed.

Values of $\mathrm{pH}$ of the effluent wastewater at the end of each experiment are shown in Table 2 at voltage of $12 \mathrm{~V}$. The value of $\mathrm{pH}$ changed due to different $\mathrm{Al} / \mathrm{OH}$ - ratios produced by $\mathrm{EC}$ cell. When initial $\mathrm{pH}$ was 4 , and 7, the $\mathrm{pH}$ increased and this due to $\mathrm{OH}$ ions generated by electrolysis followed faraday`s law. When initial $\mathrm{pH}$ was 10 , the value of $\mathrm{pH}$ decreased due to the $\mathrm{H}_{2}$ (hydrogen) production leading to a decrease in $\mathrm{pH}$.

Table 2: $\mathrm{pH}$ values after 60 minutes.

\begin{tabular}{|l|c|c|c|}
\hline Electrode & Initial $\mathrm{pH}=10$ & Initial $\mathrm{pH}=7$ & Initial $\mathrm{pH}=4$ \\
\hline $\mathrm{Al}$ & 8.6 & 7.6 & 5 \\
\hline $\mathrm{Fe}$ & 8.7 & 7.4 & 5.2 \\
\hline $\mathrm{Cu}$ & 8 & 7.5 & 5.1 \\
\hline
\end{tabular}

\subsection{Effect of Time on COD removal}

In this study, the effect of Time was studied in the range of 0 to $60 \mathrm{~min}$. Under operating conditions: $1000 \mathrm{mg} / \mathrm{linitial}$ concentration of $\mathrm{COD}$, voltage of $(3,6,9$ and $12 \mathrm{~V})$, and $\mathrm{pH}=7$, using different electrodes as anode $(\mathrm{Al}, \mathrm{Fe}$, and $\mathrm{Cu}$ ). Figures 2, 3, and 4 shows the relation between COD removal and time (in minutes) with different volts and electrodes. The figures show that COD removal increases with increase in time. By increasing EC time, more metal hydroxides generate from anode, and thus the generation of flocs increases so the coagulation process become better and removal efficiency become higher. Also, the change in the removal with further increase in time for more than 10 min is observed to be small. $\mathrm{COD}$ removal efficiency after $10 \mathrm{~min}$ using $\mathrm{Al}$ electrode as anode at $\mathrm{pH}=7$ and voltage $=12 \mathrm{~V}$ was $86.3 \%$ and after $60 \mathrm{~min}$ was $97.7 \%$. By using Fe electrode under the same operating conditions, COD removal efficiency after 10 min was $86.3 \%$ and after $60 \mathrm{~min} 96.8 \%$. Finally, by using $\mathrm{Cu}$ electrode, COD removal efficiency after 10 min was $84 \%$ and after 60 min was $96 \%$. For this reason, the value of 10 min could be taken as the optimum value for EC process time for the three electrodes. The pollutant removal efficiency does not increase after a certain time as enough flocs are available for the removal of the pollutant. 


\subsection{Effect of voltage on COD removal}

As shown in figures 2, 3, and 4, the voltage and current have a main important role in increasing the removal efficiency at the same $\mathrm{pH}$. By using $\mathrm{Al}$ electrode as anode with constant $\mathrm{pH}=7$, time $60 \mathrm{~min}$, COD removal efficiencies were 92.4, 94.6, 95.9, and 97.7\% at voltages of 3, 6, 9, and 12V, respectively. By using Fe electrode as anode under the same operating conditions, COD removal efficiencies were $91.1,93.5,95$, and 96.8 respectively finally by using $\mathrm{Cu}$ electrode as anode the removal efficiency of COD was $90.3 \%, 92.9 \%, 94 \%$, and $96 \%$ at voltages of 3, 6, 9, and $12 \mathrm{~V}$, respectively. The current induced at 3, 6, 9 and $12 \mathrm{~V}$ were observed as $0.1,0.3,0.6$ and $0.9 \mathrm{~A}$, respectively.

Current density determines both coagulant dosage and bubble generation rates and influences both solutions mixing and mass transfer at the electrodes [14]. COD removal efficiency increased with increase in voltage due to the increase in metal ions dissolute from anode. According to Faraday's law, as metal hydroxide increases, it adsorbs more COD. Also, it is well known that voltage and current density determines the production rate of coagulant, adjusts also bubble production, and hence affects the growth of flocs [5].

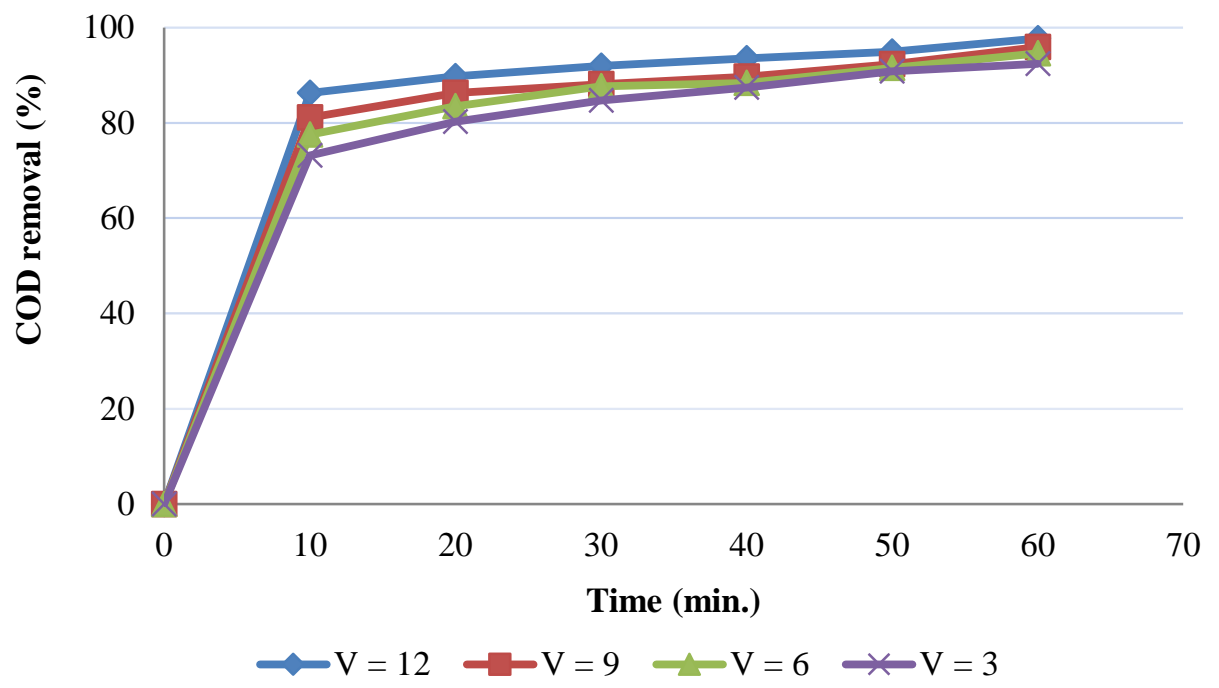

Fig. 2: $\mathrm{COD}$ removal over time using $\mathrm{Al}$ electrode as anode at different voltage, initial $\mathrm{pH}=7$, and initial $\mathrm{COD}=1000 \mathrm{mg} / \mathrm{l}$.

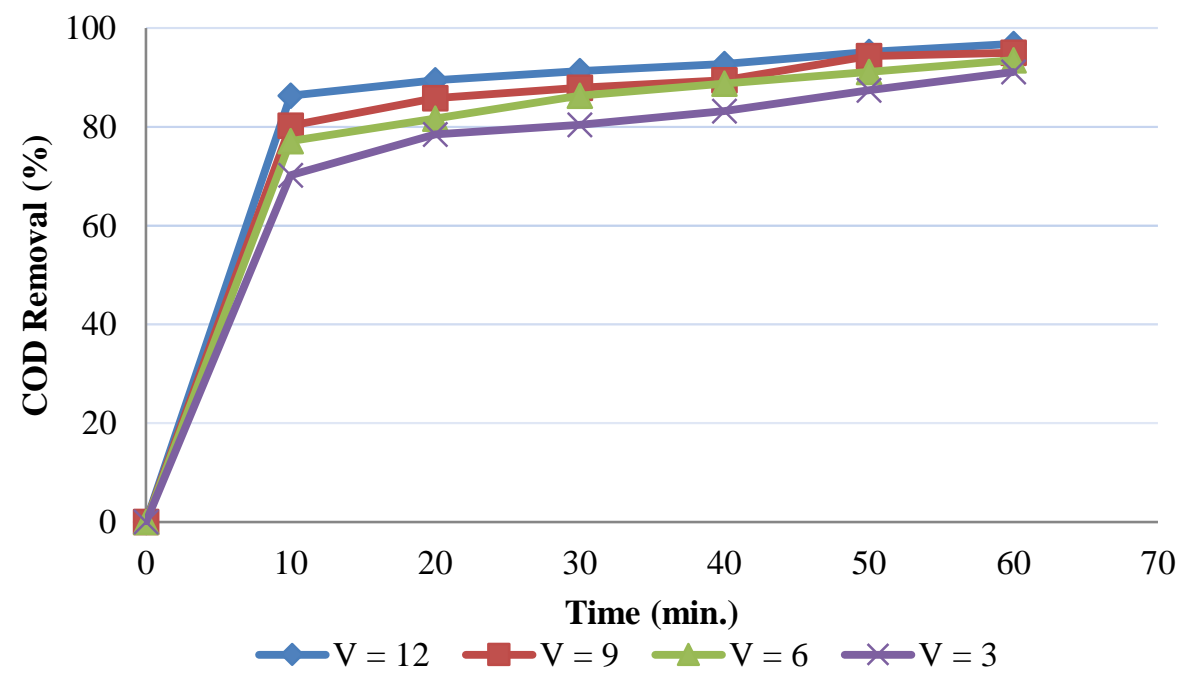

Fig. 3: COD removal over time using Fe electrode as anode at different voltage, initial $\mathrm{pH}=7$, and initial $\mathrm{COD}=1000 \mathrm{mg} / \mathrm{l}$. 


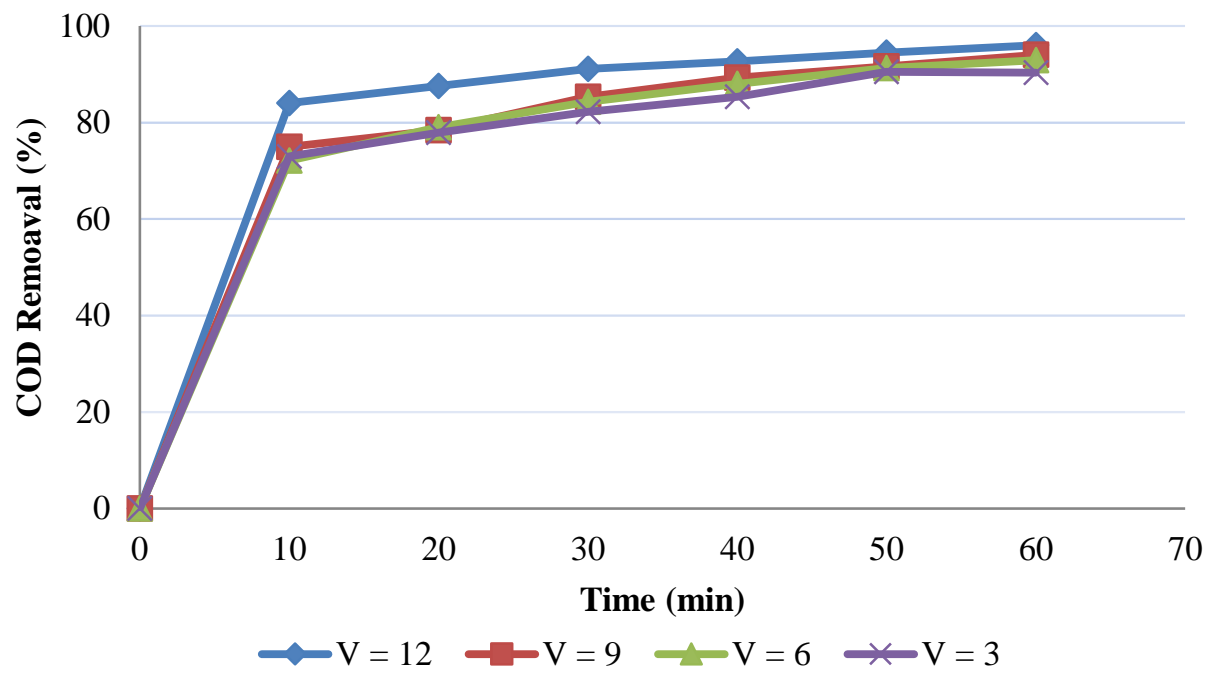

Fig. 4: COD removal over time using $\mathrm{Cu}$ electrode as anode at different voltage, initial $\mathrm{pH}=7$, and initial $\mathrm{COD}=1000 \mathrm{mg} / \mathrm{l}$.

$\mathrm{Al}, \mathrm{Fe}$, and $\mathrm{Cu}$ electrodes were used because they are cheap, so it can be used in large-scale plants. The maximum COD removal efficiency was $97.7,96.8$, and $96 \%$ for $\mathrm{Al}, \mathrm{Fe}$, and $\mathrm{Cu}$, respectively. The result showed that the $\mathrm{Al}$ electrode is better than $\mathrm{Fe}$ and $\mathrm{Cu}$ electrodes. For economical point of view, $\mathrm{Fe}$ is cheaper than $\mathrm{Al}$, however, Fe give yellow colour in water before filtration which mean the existence of dissolved iron salt in the solution.

\subsection{Case Study with Real Raw Wastewater}

The system was operated for 60 minutes to treat real raw wastewater with the characteristics shown in Table 1. Different electrodes of $\mathrm{Al}, \mathrm{Fe}, \mathrm{Cu}$ where examined at the optimum voltage $12 \mathrm{~V}$. The maximum COD removal efficiency was $91.9 \%$ and obtained using the $\mathrm{Al}$ electrode while the removal efficiency was $90.4 \%$ for Fe electrode and $90.7 \% \mathrm{Cu}$ electrode. Also, the values of $\mathrm{pH}$ of the treated real wastewater at the end of each experiment were increased. This increase in $\mathrm{pH}$ value might be due to $\mathrm{H}_{2}$ evolution at cathodes and formation of metal hydroxides at the anode which increase the concentration $\mathrm{OH}$ ions in water. $\mathrm{pH}$ increased from 7.2 to 7.8, 7.6, and 8.2 for $\mathrm{Al}, \mathrm{Fe}, \mathrm{Cu}$ electrodes, respectively.

Overall the performance of three electrodes on treating real wastewater is shown in Table 3 . The table shows the removal efficiency of COD, TDS, and TSS. The three electrode materials have almost the same removal efficiency for TSS and BOD. Ammonia removal was poor where it was reduced from $10.5 \mathrm{mg} / \mathrm{l}$ to 9.1, 9.2, $8.5 \mathrm{mg} / \mathrm{l}$ for $\mathrm{Al}, \mathrm{Fe}$, and $\mathrm{Cu}$ electrodes. The concentration of Aluminium, $\mathrm{Fe}$, and $\mathrm{Cu}$ in the treated effluent water was determined. Al concentration in the effluent water was $0.14 \mathrm{mg} / \mathrm{l}$ when using $\mathrm{Al}$ electrode, while Fe reduced from $0.1 \mathrm{mg} / \mathrm{l}$ to $0.05 \mathrm{mg} / \mathrm{l}$ when using Fe electrode. By using $\mathrm{Cu}$ electrode as the anode, $\mathrm{Cu}$ in the effluent water was $0.95 \mathrm{mg} / \mathrm{l}$. From these results, use of copper is not recommended for Electrocoagulation as elevated copper concentration could be restricted by environmental regulations.

Raw data presented in this paper will be used for a further kinetic study. Further data collection is required to determine exactly the sludge quantity produced by EC when treating municipal wastewater as the sludge handling represents a high portion of the operational costs. Disposal of sludge without treatment could cause negative environmental and public health problems [15].

Table 3: Comparison between the three electrodes when treating real wastewater.

\begin{tabular}{|l|c|c|c|}
\hline \multirow{2}{*}{$\begin{array}{l}\text { Electrode/ } \\
\text { Parameter }\end{array}$} & \multicolumn{2}{|c|}{$\mathrm{Cu}$} & \multicolumn{2}{c|}{$\mathrm{Fe}$} & $\mathrm{Al}$ \\
\hline COD & $90.7 \%$ & $90.42 \%$ & $91.9 \%$ \\
\hline BOD & $92.2 \%$ & $88.5 \%$ & $88.5 \%$ \\
\hline Ammonia & $13.3 \%$ & $12.4 \%$ & $18 \%$ \\
\hline TDS & $54.9 \%$ & $43.2 \%$ & $48.6 \%$ \\
\hline TSS & $90.4 \%$ & $89.9 \%$ & $90.4 \%$ \\
\hline
\end{tabular}




\section{Conclusion}

EC is an efficient treatment process which needs less footprint compared to conventional chemical coagulation. Moreover, unlike biological treatment that can be inhibited by the existence of toxic compounds or $\mathrm{pH}$ [16], EC can be used for the treatment of industrial wastewaters or in WWTPs that receive mixed domestic and industrial wastewaters. The present study investigated the efficiency of a batch-scale EC cell as a simple process to treat synthetic and real wastewater using with different anode materials $(\mathrm{Al}, \mathrm{Fe}$, and $\mathrm{Cu}$ ). The experimental results showed that $\mathrm{COD}$ removal efficiencies increased by increasing the Time, conductivity and the voltage. The highest COD removal efficiency achieved at $\mathrm{pH}=7$. It was found that the difference electrodes have different effectiveness in COD removal and an Al electrode was the most effective electrode in the treatment of synthetic and real wastewater with removal efficiency up to $97.7 \%$ and $91.1 \%$ for synthetic and real wastewater, respectively.

\section{References}

[1] A. Elawwad, "Optimized biological nitrogen removal of high-strength ammonium wastewater by activated sludge modelling," Journal of Water Reuse and Desalination, vol. 8, no. 3, pp. 393-403, 2018.

[2] M. Nasrullah, Md. Nurul Islam Siddique, A.W. Zularisam, "Effect of High Current Density in Electrocoagulation Process for Sewage Treatment," Asian Journal of Chemistry, vol. 26, no. 14, pp. 4281-4285, 2014.

[3] P. Aswathy, R. Gandhimathi, S. T. Ramesh, P. V. Nidheesh, "Removal of organics from bilge water by batch electrocoagulation process," Separation and Purification Technology, vol. 159, no. 8, pp. 108-115, 2016.

[4] H. Liu, X. Zhao, J. Qu, "Electrocoagulation in Water Treatment," in Electrochemistry for the Environment, C. Comninellis, G. Chen (Eds.), Springer, 2009.

[5] B. Merzouk, A. Gourich, K. Sekki, K. Madani, M. Chibane, "Removal turbidity and separation of heavy metals using electrocoagulation-electroflotation technique A case study," J. Hazard. Mater., vol. 164, pp. 215-222, 2009.

[6] S. Safari, M. Azadi Aghdam, H.-R. Kariminia, "Electrocoagulation for COD and diesel removal from oily wastewater," Int. J. Environ. Sci. Technol., vol. 13, pp. 231-242, 2016.

[7] S. Zodi, O. Potier, F. Lapicque and J. Leclerc, "Treatment of the Textile Wastewaters by Electrocoagulation: Effect of Operating Parameters on the Sludge Settling Characteristics," Separation and Purification Technology, vol. 69, no. 1, pp. 29-36, 2009.

[8] F. Hanafi, O. Assobhei, and M. Mountadar, "Detoxification and Discoloration of Moroccan Olive Mill Wastewater by Electrocoagulation," Journal of Hazardous Materials, vol. 174, no. 1-3, pp. 807-812, 2010.

[9] R. Katal and H. Pahlavanzadeh, "Influence of Different Combinations of Aluminium and iron electrode on electrocoagulation Efficiency: Application to the Treatment of Paper Mill Wastewater," Desalination, vol. 265, No. 1-3, pp. 199-205, 2011.

[10] A. Elawwad, M. Rageb, H. Abdel-Halim, "An economical, environmental and social comparison between vacuum and gravity sewers in decentralized sanitation systems, with Egypt as a case study," Journal of Water Sanitation and Hygiene for Development, vol. 5, no. 4, pp. 614-619, 2015.

[11] E. W. Rice, R. B. Baird, A. D. Eaton, "Standard Methods for the Examination of Water and Wastewater," $23^{\text {rd }}$ Ed., New York: WEF, 2017.

[12] N. Daneshvar, A. R. Khataee, A. R. A. Ghadim, M. H. Rasoulifard, "Decolorization of C.I. Acid Yellow 23 solution by electrocoagulation process: Investigation of operational parameters and evaluation of specific electrical energy consumption," Journal of Hazardous Materials, vol. 148, pp. 566-572, 2007.

[13] R. Gandhimathi, A. Babu, P. V. Nidheesh, S. T. Ramesh, T. S. Anantha Singh, "Laboratory Study on Leachate Treatment by Electrocoagulation Using Fly Ash and Bottom Ash as Supporting Electrolytes," Journal of Hazardous Toxic and Radioactive Waste, vol. 19, no. 3, 2015.

[14] Heidmann, W. Calmano, "Removal of $\mathrm{Zn}(\mathrm{II}), \mathrm{Cu}(\mathrm{II}), \mathrm{Ni}(\mathrm{II}), \mathrm{Ag}(\mathrm{I})$ and $\mathrm{Cr}(\mathrm{VI})$ present in aqueous solutions by aluminium electrocoagulation," Journal of Hazardous Materials, vol. 152, pp. 934-941, 2008.

[15] A. Elawwad, M. Hazem, "Minimization of sludge production in an integrated UASB-continuous flow sequencing batch reactor system," Desalination and Water Treatment, vol. 91, pp. 206-213, 2017.

[16] A. Elawwad, M. S. Zaghloul, H. Abdel-Halim, "Simulation of municipal-industrial full scale WWTP in an arid climate by application of ASM3," Journal of Water Reuse and Desalination, vol. 7, no. 1, pp. 37-44. 2017. 